\title{
Heroes and Villains: Ijaw Nationalist Narratives of the Nigerian Civil War
}

\author{
Kathryn Nwajiaku-Dahou*
}

\begin{abstract}
Numerous explanations of the failure of the Biafran enterprise highlight the absence of legitimacy and support for the Biafran effort among the Niger Delta 'minorities'. In the aftermath of the Civil War, popular narratives among the Ijaw, arguably Nigeria's fourth largest ethnic group, tended to tie them closely to the Federal side. In this paper, we examine the transformations of the relationship between Southern minorities and the Biafran cause, with a particular focus on the Ijaw. The fiscal centralization of oil resources that followed the war and the persistence of minority exclusion within the Nigerian polity have encouraged Ijaw elites, and other southern minorities, to review their commitment to Nigerian federalism. Conflicting tales of the Ijaw nationalist hero Isaac Boro testify to a growing 'revisionism' in interpretations of the Biafran War. Today the resurgence of militant forms of Ijaw ethnic nationalism, against the backdrop of oil community protests which have been taking place since the early 1990s, has given rise to new interpretations of the war, and the creation of new political linkages between Ijaw nationalists, other Niger Delta minorities and Igbo proBiafra movements. While resistance to Biafra catalyzed Ijaw nationalism in the fighting and aftermath of the Civil War, Biafra has now become a symbol of contemporary Ijaw nationalism. By drawing on new 'revisionist' histories of Biafra, this paper considers the complex interaction of ethnic nationalism, oil and secessionist conflict in Nigeria.
\end{abstract}

\section{Résumé}

De nombreuses explications de l'échec de l'entreprise du Biafra mettent en évidence l'absence de légitimité et de soutien à l'effort du Biafra chez « la population minoritaire » du delta du Niger. À la suite de la guerre civile, les récits populaires chez les Ijaw, sans doute le quatrième plus grand groupe ethnique du Nigeria, avaient tendance à les lier étroitement à la partie Fédérale. Dans cet

* ESRC Research Fellow, Department of Politics and International Relations, University of Oxford. E-mail: kathryn.nwajiaku@politics.ox.ac.uk 
article, nous examinons les transformations de la relation entre les minorités du sud et la cause du Biafra, avec un accent particulier sur les Ijaw. La centralisation fiscale des ressources pétrolières qui ont suivi la guerre ainsi que la persistance de l'exclusion des minorités de la politique nigériane, ont encouragé les élites ijaw et d'autres minorités du sud à revoir leur engagement en faveur du fédéralisme nigérian. Les histoires contradictoires du héros nationaliste ijaw, Isaac Boro, témoignent d'un « révisionnisme » croissant des interprétations de la guerre du Biafra. Aujourd'hui, la résurgence des formes militantes du nationalisme ethnique ijaw, sur fond de protestations de la communauté pétrolière, qui se déroule depuis le début des années 1990, a donné naissance à de nouvelles interprétations de cette guerre et la création de nouvelles relations politiques entre les nationalistes ijaw, les autres populations minoritaires du delta du Niger et les mouvements proBiafra Igbo. Bien que la résistance au Biafra ait catalysé le nationalisme Ijaw durant et à la suite de la guerre civile, le Biafra est maintenant devenu un symbole de nationalisme contemporain Ijaw. En s'appuyant sur de nouvelles histoires « révisionnistes » du Biafra, le présent article examine l'interaction complexe entre le nationalisme ethnique, le conflit pétrolier et sécessionniste au Nigeria.

\section{Introduction}

Coming to terms with the legacies of Biafra is as much about reimagining as about remembering. In current struggles in the Niger Delta, the Ijaw, arguably Nigeria's fourth largest ethnic group, have begun to see themselves as the heirs of Biafra. Although the Ijaw largely supported the Federal side at the time of the Civil War, past Ijaw opposition to Biafra is being replaced by a new identification with the image of Biafra in contemporary struggles in the Niger Delta. Today, Ijaw revisionist narratives attempt to relocate the Ijaw more firmly in the Biafran fold, and greater links are being forged between Ijaw nationalist militants and the Igbo separatist organization MASSOB (Movement for Actualisation of the Sovereign State of Biafra). From the perspective of the Ijaw, I will show why this historical revisionism makes political sense.

Yet, as a British-born Igbo, raised on distant stories of the Biafran War, of relatives killed and maimed before I was born, a different Biafra is in my head. Injunctions not to forget, intensified by Chimamanda Ngozi Adichie's (2007) momentous recent novel, Half of a Yellow Sun, struggle in my mind with revisionist Ijaw forms of remembering. My reading of the Ijaw story, the actual and the revisionst versions, is imbued with a sense of what the French call 'parti pris'- a stake in the way the tale is told. In the search for the truth about Biafra and its meaning for contemporary Nigeria, it is important to recognize that this is one version of a story that an Ijaw narrator might have told differently. 
Numerous explanations of the failure of the Biafran enterprise highlight the absence of legitimacy and support for the Biafran effort among the Niger Delta 'minorities'. The Delta minorities were seen as the 'weakest link' in Ojukwu's strategic and military calculations, and were targeted as 'saboteurs' behind the Biafran front line. Prior to the 1990s, popular narratives among the Ijaw tended to tie them and other minorities closely to the Federal side. This picture of resistance to Biafra is best summed up by the life and times of the celebrated Ijaw revolutionary, Issac Adaka Boro, who in February 1969 attempted to create an independent 'Niger Delta Republic' and who died fighting to defend the unity of Nigeria on the side of the Nigerian army (Nwajiaku 2006). For many Ijaw elites and ordinary people alike, Isaac Boro paved the way for their ascent within the army, particularly after the erosion of the Igbo officer corps. With the Igbo emasculated militarily, it also provided a platform for their subsequent claims to being Nigeria's 'fourth largest ethnic group'. The war came to constitute a symbolic resource for the justification of the creation of Rivers State and its persistence as a terrain of Ijaw political domination between 1970 and 1996.

The intellectual production and political work of politicians, writers and academics also helped to institutionalize the 'memories' of Biafra as something southern minorities did not support. The campaiging activities of Harold Dappa Biriye, founder of the first Ijaw political party, the Niger Delta Congress, in 1956, and architect and servant of the Rivers State government-in-waiting during the war; the published works and political career of Ken Saro-Wiwa, founder of the Movement for the Survival of the Ogoni People (MASOP) and Federal Administrator of Bonny during the war; and the work of Ikwerre writer, former soldier and teacher, Elechi Amadi, provided just some of a tapestry of minority narratives that suggest that minorities were peripheral, and often antogonistic, to the Biafran enterprise.

When twelve states were created just before the Civil War to replaced the four former regions, southern minority groups initially welcomed this move as a means of freeing themselves from Igbo political domination within the regional system. State creation was used as a tool for undermining possible minority support for Biafra. Yet since the war, an expanding oil economy, progressive fiscal and political centralization, and successive rounds of state creation have meant that the states whose creation minorities had long struggled for, lost fiscal and political autonomy. The target of minority political frustrations therefore shifted away from the regions to the centre, away from a specific focus on the once regionally powerful 'Igbo' to the 'wazobia' or majority-three ethnic groups, particularly the Hausa-Fulani elites, who, until 1999, controlled power at the Federal centre. This meant they also 
controlled the ownership and distribution of oil revenues, from which the Delta minorities, despite the location of their homelands in the key oil producing region, have failed to benefit.

Throughout the 1970s and 1980s, minority political struggles had centred on how to eke out greater spheres of influence at the political centre - that is, how to become more effective clients of the most powerful ethnic groups. The political emasculation of the Igbo and the creation of states, notably Rivers State, with its expanded 'oil' capital Port Harcourt, emboldened the power of Ijaw from the eastern and parts of the central Delta, who came to constitute the largest minority group in the region and maintained a political culture of allegiance to 'the North', that is, to the Northern Hausa-Fulani political establishment. However, market reforms and intensifying economic hardship since the late 1980s have closed many of these avenues of advancement, and generated protests in the oil communities of the Delta, and a growing challenge to an Ijaw elite culture of accommodation with the Hausa-Fulani elite. Against this backdrop new interpretations of the war, and the role of the Ijaw in it, are emerging that emphasize their role and that of other minority groups on the side of the Biafran project.

As a result, remembering Biafra pulls Ijaw nationalists and other southern minorities in two different directions. The historical facts tell a story of Ijaw elites and their people opposed to Biafra and supportive of the Frederal Government and a united Nigeria. This reading sits uncomfortably with the widespread anti-Federal government undercurrent that informs contemporary minority nationalisms throughout the Niger Delta. As the first bold, albeit unsuccessful, attempt at secession the country has known, Biafra provides a template of 'resistance' from which present-day ethnic struggles seek to draw inspiration, as evidenced by the political links established as early as 2001 between the Ijaw Youth Council, under the leadership of Alhaji Asari Dokubo, and the militant Igbo-led organization, the Movement for the Actualization of the Sovereign State of Biafra (MASSOB), dedicated to reviving the Biafran project.

This paper's attempt to 'excavate' the past is evidently complicated by contemporary political struggles over oil. The role of oil in the Biafran War, not so much as the key driver of secession itself, but as an important motivation behind Biafran, Federal and international involvement in the conflict, further complicates matters. The centrality of oil today to minority struggles in the oil-producing Delta makes it difficult for popular narratives to divorce the Biafran project from a desire by the Igbo regional majority at the time to control the oil wealth. This links the idea of Biafra with ethnoregional struggles and the politics of oil, both then and now. 
This paper is divided into three parts. The first looks at who the Ijaw were prior to the war - their sense of group consciousness and the nature of their political allegiances. This serves in part as an explanation of the content of the second part, which unravels the multiple narratives of the experiences of the Ijaw during the war. The third part places these narratives within the broader context of contemporary projects of Ijaw ethnic nationalism, and concludes with reflections on present reinterpretations of the past in the light of Ijaw alliances with today’s Biafra project.

\section{Ijaw Identity Before the War}

\section{Political Awakenings}

Today in Nigeria, Ijaw broadly refers to a group of some 8-12 million people, scattered across the six states of Nigeria's Atlantic coastline, from Ondo State in the west to Akwa Ibom in the east. This explains their claim to being Nigeria's 'fourth largest' ethnic group and, although a minority in the Nigerian context, the largest minority group in Nigeria's oil-producing Niger Delta region, and arguably in the nation as a whole. However, the Ijaw have not always been members of a single ethnic identity. The last two decades of oilinduced community uprising in the Niger Delta have consolidated the emergence of a broad-based pan-Ijaw ethno-nationalist consciousness among a swathe of people, speaking variants of some six related though not mutually comprehensible languages, with a diverse set of histories and social relationships with non-Ijaw groups and political cultures.

While today's vocal and vibrant Ijaw nationalism suggests the existence of a relatively homogeneous group, we would also emphasize the relatively recent character of pan-Ijaw ethno-political consciousness. Ijaw identity involves deep fissures that continue to divide the Ijaw based on a diversity of social and ecological histories, which have shaped the development of internal divisions and external relations with non-Ijaw groups within the Delta and beyond, particularly with the Igbo of the hinterland to the north of the Delta. Competition with the Igbo majority of Nigeria's Eastern Region has served as an important crucible for the emergence of an Ijaw nationalist identity.

The long histories of exposure to Europe since the sixteenth century, through the intermediary roles played by eastern and central coastal Ijaw as 'middlemen' in the trans-Atlantic trade in mainly hinterland Igbo slaves and later in palm oil products, created complex social and political institutions and strong 'city state' rather than specifically 'Ijaw' identities. These were particular to the coastal Ijaw whose creeks and rivers were mainly saltwater ones bordering the Atlantic coast in the central and eastern Delta (Nembe, Kalabari, Okrika, Ibani). This early ‘exposure’ to all things European paved 
the way for the 'warrant chief'/'court clerk' role played by many of their elites in the early colonial administration. By contrast, many upland freshwater Ijaw communities in the northern parts of the central and western Delta had more in common with Igbo societies further north as sites of slave raids and later of palm oil production. In addition to being geographically closer to the Igbo hinterlanders, the freshwater Ijaw shared similarities in social and political structures leaving them open to caricatures of 'backwardness' in the eyes of Ijaw 'kin' from the more 'civilised' coast (Jones 1963).

The seeds of a pan-ethnic political identity, however, were gradually sown in the early 1930s and 1940s amid growing competition for influence and resources in the colonial administrative centre of Port Harcourt. Ijaw migrants and other Delta communities found themselves in competition for jobs, political influence and land with the vast numbers of Igbo migrants from the north of the Niger Delta. The sheer size of the Igbo migrant population to Port Harcourt changed the demographics of the town. This meant that political organization based on a pan-Ijaw communal identity alone would be insufficient to counter Igbo ascendancy. In the context of decolonization, the creation of three regional political units in 1946, each with an ethnically dominant 'majority' group and a large number of smaller 'minorities', became the crucible of trans-ethnic 'Rivers'/'minority' identities developed to do battle with the hinterland Igbo. Throughout the 1950s period of episodic deliberations over Nigeria's constitutional future, a Calabar-Ogoja-and-Rivers political identity also emerged, which included an even larger stretch of non-Igbo minority groups living in three provinces in the eastern region. Both minority political platforms used notions of cultural similarity to make a case for greater 'minority' autonomy vis-à-vis the politically and numerically dominant Igbo ethnic group that dominated the Eastern Region and controlled the largest political party, the NCNC, which also controlled the Regional government (Tamuno 1972).

Set up by the 1956/7 Conference to calm minority anxieties over majority domination, and pending independence, the Willink Commission of Inquiry into Minority Fears and Means of Allaying Them, marked an important turning point in the Ijaw political awakening. During and prior to the Willink Commission, pan-Ijaw, Rivers, intra-Ijaw and Niger Delta identities competed for space as the political platform of preference. The Willink Commission resolutely refused to accede to minority demands for state creation but designated the area to be covered by the Niger Delta Development Board as an 'Ijaw Special Area', which was carried out after the much-sought-after Port Harcourt and Ahoada had been excluded from it. Although the Ogoni were still included within the new Ijaw Special Area, Willink's recommendations brought to light new cleavages between the Ijaw and 
non-Ijaw in Rivers Province, which grew after the eventual creation of a Rivers State in 1967. Many had long suspected the Ijaw of using 'Rivers' as a smokescreen for what was effectively an exclusively Ijaw political project. Not all Ijaw, however, supported the idea of creating a Rivers State, particularly the politically and economically powerful Kalabari chiefs who advocated a COR state (based on the boundaries of Calabar, Ogoja and Rivers Provinces) rather than a Rivers State per se.

After Willink, both the Western and Eastern Regional governments introduced a mixture of palliative and coercive measures to contain minority demands for state creation. In the East, the previous government clamped down on supporters of the Rivers State movement, and used the newly created second chamber, the Regional House of Chiefs (1957/8), to ensure compliance from chiefs and ordinary people at town and village levels. As a palliative gesture, new provinces out of the former divisions were also introduced. Willink's sop to minorities - the creation of a Niger Delta Development Board - was unable to promote the development of the Niger Delta region because it had no budgetary oversight and was reliant on the munificence of the Eastern and Western Regional governments in the form of grants. Political realism made it important to be seen to support the Eastern Government and not to be perceived as anti-Igbo, which would have meant denying oneself and one's constituents access to political patronage and public resources.

New rivalries emerged within the Rivers coalition. The Rivers Chiefs and Peoples Conference, led by Harold Dappa Biriye, who had championed the creation of the first Ijaw ethnic associations in Port Harcourt, and led the Rivers State creation cause, split into two factions. The larger faction, made up of chiefs and some younger educated men, opted for accommodation with the NCNC government. A smaller faction organized around a new party, the Niger Delta Congress (NDC), created by Dappa Biriye in May 1959, was opposed to any accommodation with the Eastern Region's NCNC government. The NDC formed an alliance with the a rival party in the Northern Region, the NPC (Northern People's Congress) prior to the 1959 Federal elections, ostensibly because the NPC 'promised', once in power, to create a Rivers State as a Federal territory.

Dappa Biriye's NDC managed to secure one seat in the 1959 elections, yet regionally the NCNC remained powerful, taking back the seat in 1964 . The discovery of oil in commercial quantities in Oloibiri district in 1956 may have given some Ijaw elites a 'renewed sense of indispensability', echoing memories of their central role in the slave and palm oil economies and a new sense of injustice for not being granted what was deemed to be owed to them (Eboreime 1992). At the time, it did not make political sense for them 
to pursue an ethnically exclusive Ijaw nationalist agenda. Seeking Federal protection or support yielded little fruit, as the NDC, which had placed its hopes of greater autonomy in its alliance with the Northern Region's NPC, learnt to its cost after 1959 when its Northern ally formed a Federal coalition with the Igbo-dominated NCNC.

The NCNC government often rewarded Ijaw who were among the party faithful. Northern Ijaw, particularly among 'ethnically peripheral' groups like the Edoid-speaking Ijaw groups (Epie Atissa), tended to vote NCNC in elections, because their well-placed sons-of-the-soil were in the party and could extract generous grants. Deep party political cleavages, however, existed between elites from different villages and between NCNC and non-NCNC supporters. Those cleavages in parts of the Delta continue to this day. NCNC administrative reforms, the creation of county councils and of new chieftaincy stools, and the multiplicity of avenues for 'bringing the government closer to the people', ensured NCNC hegemony and control. Perceived party opponents (presumed NDC supporters) were the object of violent reprisals. NCNC patronage also upset traditional intra-Ijaw hierarchies, with formerly 'chiefless' societies being granted 'cheifly' status, allowing them to oust rival erstwhile overlords from the coastal city states and creating new intra-ethnic cleavages. Prior to independence, regional rather than central power determined the distribution of social goods. It made pragmatic sense for Ijaw elites to build cliental relations with the NCNC regional government. This was to change, however, as fiscal and political power gradually shifted towards the Federal centre after independence, particularly following the January 1966 military coup. Although initially an ideological stance, Harold Dappa Biriye's continued advocacy of an Ijaw special area directly administered by the Federal government, backed by closer ties with a Hausa-Fulani led central government, and an electoral pact with the NPC, were also pragmatic moves, in the light of the shift of power to the centre. In a similar vein, as we will see below, today's eponymous hero and Ijaw nationalist icon, Isaac Adaka Boro, advocated the same close ties, describing Nigeria's first Prime Minister, Tafawa Balewa, as 'the protector of all Ijaws'. Yet while Harold Dappa Biriye, who until his death in 2005 continued to advocate an Ijaw-Hausa-Fulani alliance, attracted widespread vilification among Ijaw nationalists from the 1990s onwards, Isaac Adaka Boro has become an ethnic hero and icon for advocating essentially the same strategy. His saving grace was perhaps that he died young and 'on the battlefield' before the political realities changed.

\section{Ijaw and the Unravelling of the First Republic, 1959-66}

The lopsided political structure that existed prior to the Civil War, originally based on three powerful regions, created intractable problems of 
ethno-regional competition and instability. While the larger Northern Region controlled a majority of seats within a central parliament, the two smaller Eastern and Western Regions jostled for junior partnership within a ruling coalition, entrenching ethnic and religious hostilities, which plagued and finally destroyed Nigeria's First Republic. As we have seen, tensions within each region between minority ethnic groups and ethnic majorities could be persistently exploited by rival political parties, each seeking to make inroads into the regional fiefdoms of the opposition, as a means of challenging their status at the political centre.

The prelude to the military coups of 1966 that dismantled the First Republic, and the descent to civil war in 1967 have been well rehearsed elsewhere. The critical points to emphasize here are that in the run-up to war, the Igbo and their leaders were initially advocates of Federalism, supporting the existing Nigerian system of strong regions and a weak centre. The Hausa-Fulani-dominated Northern Region, however, which controlled a majority of seats within a central parliament, had growing reasons to favour a stronger centre, particularly after the discovery of oil in the East cast the regional system of resource control in a new light. These underlying stresses, overlaid by increasingly ethnic interpretations of the two coups and the massacre of Igbo civilians in northern cities (along with many Ijaw and other Eastern minorities, generically perceived as Igbo in the North), culminated in the mass return of Igbos to the East and initial moves toward secession by the Military Governor of the Eastern Region, Lt General Ojukwu, in May 1967. Even then, Ojukwu initially claimed to be unilaterally implementing agreements reached in Aburi, Ghana to resolve the crisis, agreements on which he claimed the Nigerian Head of State, Lt Colonel Yakubu Gowon, had reneged.

The name Biafra was allegedly suggested by Frank Opigo, an Ijaw NCNC stalwart, but the vision for 'Biafra' was articulated by Eastern, mainly Igbo, intellectuals, who envisaged a new, self-reliant society. A number of Eastern intellectuals had returned to the East from Federal government posts and the Federal universities in Lagos and Ibadan, feeling their positions to be under threat owing to virulent political attacks by the Western Regional Government against 'Igbo over-representation' at the Federal level. The University of Nigeria at Nsukka became the intellectual hub of the 'Biafran' project. The pogroms against Igbos in the North and the frenzied return of refugees 'home' to the East added further ammunition to the idea of an independent Biafra (de St Jorre 1989:40).

Gowon attempted to counter Ojukwu's manoeuvres by institutinging a state of emergency, declaring a number of acts of the Eastern Region government illegal, and announcing the end to the regions and the creation of 
twelve states. The Eastern Region was divided into three states, only one of which was controlled by the Igbo; the former Western Region formed three states, two of which were core Yoruba states; and the Northern Region formed six states, three of which were dominated by the Hausa-Fulani. To add insult to injury, the new Igbo state was landlocked. Three days later, on 30 May, Ojukwu officially declared the independent 'Republic of Biafra' (Williams 1982:31). Federal troops invaded Biafra on 17 July 1967, beginning a civil war that finally ended when Ojukwu fled to Côte d'Ivoire, and MajorGeneral Philip Effiong, his Chief of Staff, surrendered on 12 January 1970.

\section{Ijaw Reponses to Coup, Counter-Coup and War}

Although many prominent Ijaw elites were part of the NCNC political establishment, Ijaw nationalist narratives today emphasize their opposition to the Eastern Regional Government, as epitomized by the life and works of Isaac Adaka Boro. The selective 'cutting and pasting' of Boro's story and debates among the Ijaw about the content of his legacy also reflect deeper divisions among Ijaw nationalists today over strategy. On the one hand are those in favour of tying Ijaw fortunes to an alliance with Hausa-Fulani elites and who deplore revolutionary tactics, and on the other lie those who advocate an end to Hausa-Fulani alliance-building in favour of a strategy of armed struggle.

Aspects of Boro's life appeal to both sides, yet it is for the advocates of regional autonomy possibly culminating in a break with 'One Nigeria', that Boro's legacy is the most problematic. While Ijaw advocates of local autonomy and resource control are now eager to build bridges with emergent Biafra revivalist movements, like MASSOB, they have adopted a hero whose life strikes at the heart of what Biafra stood for. The Biafran struggle for secession contrasts with Boro's loyalty to the Federal army, raising important existential questions for Ijaw nationalists who vilify the Nigerian Federal government for having appropriated and squandered the petroleum resources of the Niger Delta. Yet Boro's revolutionary credentials, military prowess and stance on the question of local ownership of petroleum resources also make him a useful heroic figure for contemporary Ijaw nationalist champions of 'resource control'.

Although Boro's story is just one of many, its prominent place in Ijaw nationalist 'official history' makes it worthy of particular consideration. Isaac Adaka Jasper Boro was born on 10 September 1938 in Oloibiri, Ogbia district, the son of Pepple Boro, the headmaster of the only mission school in Oloibiri at the time. In the early 1940s, he moved with his parents to Port Harcourt before settling in Kaiama, the native town of his father, who took up the post of headmaster at the Reverend Proctor Memorial School. Kaiama was a major centre for the freshwater Kolokuma and Opokuma Ijaw in Brass division, later Yenagoa Province, and the first Ijaw town outside the coastal eastern Delta to 
have gained access to missionary education. From an early age, Boro's outlook, like that of many of those who later became Ijaw nationalist leaders, was informed by an experience of travel throughout the Delta. After secondary schooling in Warri, a brief stint as a teacher and later in the police force, in 1961, he obtained a two-year scholarship from the Eastern Regional Government. Boro enrolled at the University of Nigeria, Nsukka (UNN) to read chemistry. His experience of student politics at UNN, where the prized position of Student Union President, who controlled a budget of $£ 5,000$, was hotly contested, profoundly marked his political outlook. In his posthumously published 'autobiography', Boro claims that 'tribalism', which relegated the Ijaw to the position of 'strangers' within their own region, was the cause of his two consecutive but failed attempts at becoming Student Union President (Tebekaemi 1982:47). In spite of the 'tribal onslaught' and a majority Igbo electorate, Boro managed to get himself elected in the post in 1964.

The position gave him privileged access to politicians within the Eastern Regional Government who were keen to use him to 'organize' opposition to the 1964 Federal Elections but were reluctant to countenance the idea of the creation of a state for the Niger Delta, which he wanted to be 'strictly ... occupied by the Ijaws' (Tebekaemi 1982:57). He described 'The North' as the only true 'benefactor' of the Ijaw (Tebekaemi 1982:55). Upon graduating from UNN in 1965, Boro moved to Lagos, where with fellow Kaiama son, Samuel Owonaro (son of the first Ijaw person to write a 'History of the Ijaw), and Nottingham Dick, he founded a political movement, called the Integrated WXYZ, which advocated greater control of the benefits of oil wealth for the Ijaw.

After toying with the idea of reformist politics, Boro claimed that the killing of Prime Minister Tafawa Balewa, whom he described as the 'protector' of all Ijaws, and the installation of the Igbo officer, Major General AguyiIronsi, convinced him that revolution was the only way out for the Ijaw. Boro advocated a rejection of the new regime, which he told his followers to have nothing to do with (Tebekaemi 1982:122). From 22 January 1966, Boro, Owonaro and Dick returned home and began to recruit young men between the ages of 18 and 33 to join the Niger Delta Volunteer Service. A camp was opened behind his father's compound in Kaiama, in Taylor Creek, a tributary of the River Nun. In three week some 120 recruits were enlisted. These were instructed to seize all motor boats belonging to the Nigerian Government and oil companies but not to harm any expatriate worker (Tebekaemi 1982:18). After less than a month of training in guerrilla tactics with funds raised through the seizure of goods from illicit gin sellers, accompanied by the stockpiling of explosives, which were easy to acquire because they were widely used by the oil industry and available in local 
markets, and contacts established in Yenagoa, Ahoada, Degema, Oloibiri, Patani and Bomadi, Boro's Niger Delta Volunteer Service launched its offensive to establish the Niger Delta Republic on 23 February 1966.

After a swearing-in ceremony in English and 'Ijaw', using a mixture of Christian benediction ritual and indigenous Egbesu purification rites, a declaration of independence was read out. Eastern Regional Government and Federal institutions including police stations, outposts of the Niger Delta Development Board and schools, were subsequently closed down and the declaration read to state officials. Most non-Ijaw administrators, notably the military-appointed Sole Administrator of Yenagoa Province, fled. Many nonnatives also left from what had previously been the multi-ethnic provincial headquarter town of Yenagoa. Boro was explicit about his desire to reclaim the Niger Delta for the Ijaw alone. State administrators of non-Ijaw origin were particularly singled out for punishment 'for the sins of (their) Race'. The looting of non-Ijaw shops in Yenagoa was actively encouraged, and referred to as the collection of a 'non-Ijaw tax' (Tebekaemi 1982:127). After just twelve days the revolution was quashed, and Boro and his men arrested and imprisoned for treason.

In spite of Boro's stated objective to use the revolution to resist at all costs what he perceived as an illegal Igbo-led coup, others have suggested that Boro's efforts were more of a provocation than a genuine succession attempt. Ruth First argues that Boro and his men were in league with senior Northern officers, and had wanted to use the threat of revolution to trigger the imposition of a state of emergency by the Northern-led Federal government prior to the first coup. Boro himself admitted to being close to the TafawaBalewa government, and having little sympathy for the government of the Eastern Region. However, by the time Boro's revolution saw the light of day, the national political landscape had been so drastically altered that even if a Northern-sponsored state of emergency had been the original plan, it was no longer feasible. In the end, Boro's revolution was a last-ditch attempt to show that the Niger Delta was snubbing the Igbo-led military regime established after the first coup. Commenting on the likelihood of success, Boro declared, 'As for success, it was ... better to call the attention of the world to the fact that the inhabitants of the Niger Delta in Nigeria were feeling very uncomfortable. ... Let the success be a magnanimous grant from Lord Providence'.

The July 1966 coup changed the situation once again. In August 1967, one year and six months after their initial campaign, Boro, Owonaro and Dick were granted clemency and all joined the Nigerian army, in Boro's words to 'free people from Biafran occupation'. ${ }^{1}$ Ijaw migrants from as far away as Ghana, who had been expelled by the Busia government and were 
stranded in and near Lagos, also joined up. Isaac Boro was given ample scope to recruit his own force of some 1,000 'ill-disciplined, hurriedly and poorly trained Rivers men', who joined the Third Marine Commando Division in Bonny (Obasanjo 1980:47). While Samuel Owonaro and Nottingham Dick stayed with half the recruits in Bonny (the latter subsequently lost his life there), Boro and the remaining recruits, equipped with sophisticated 23calibre rifles, joined the rest of the Third Marine Commando Division, and took part in the Calabar landing operation, known as 'Operation Tiger Claw' - a name by which Boro's men subsequently became known. ${ }^{2}$

After a number of much-celebrated victories against the Biafran forces, Boro died in 1969, shortly before the war ended, provoking much controversy about the circumstances of his death. Some claim he died in battle in Bonny or in Port Harcourt, while others suggest he was murdered by his commanding officer, Col. Benjamin Adekunle, who was jealous of Boro's rapid rise within the army - a story that resonates with contemporary Ijaw feelings of Yoruba and Federal government treachery in dealings over oil resources. Calls for a full investigation into the circumstances surrounding Boro's death are regularly made, particularly around 15 May, the anniversary of his death, during which ritualized processions to Kaiama from all over the Niger Delta take place, amid week-long festivities. ${ }^{3}$ Yet while the presence of Ijaw members of the armed forces at his anniversary ceremonies emphasizes the iconic figure of Bor as the Federal Soldier victorious against the Biafra secessionist, Ijaw nationalists are keen to highlight the important role the Ijaw and other minorities played on the Biafra side during the war. Ijaw nationalist militant Alhaji Asari Dokubo, who models himself as Boro's heir, before his arrest in 2005 openly expressed a commitment to the break-up of Nigeria (Amaize 2005). In 2002 he claimed that Boro's death was caused by the wrath of the Ijaw gods, angry that he had left behind the struggle to fight instead on the side of the Nigerian Government, which he had initially fought to undermine. Boro was doing something contre nature and therefore paid the heavy price for it. ${ }^{4}$ It is now difficult to get at any 'truth' surrounding the actual circumstances of Boro's death. What is most important about these accounts is how they 'frame' Boro, his life and death, as an important plank in the history of the 'Ijaw nation' as a whole. The speculation and controversy surrounding his death further reinforce his hagiographic status.

\section{Ijaw Elites and the Creation of Rivers State}

Resistance to the first military coup and to the declaration of Biafran secession also took more conventional constitutional forms, epitomized by the path trodden by Chief Harold Dappa-Biriye, Ijaw leader of the Niger Delta Congress Party. Initially obliged to work with the Eastern government in 
fear for his own life and safety, he kept channels of communication open with the Federal Government and subsequently moved to Lagos to become part of the Rivers State government 'in exile'. Dappa-Biriye, like Boro, saw the way forward through an alignment with the Northern political elite, but distanced himself from Boro's attempted revolution, later claiming that 'he was too young ... to bring near' ${ }^{5}$ This did not prevent Dappa-Biriye from being placed under house-arrest after Boro's revolution was crushed because he was perceived as being linked with him and therefore a security risk. The desire of the Gowon military government to stifle the establishment of a Biafran republic created a new opportunity for Biriye to pursue his ambition for the creation of a Rivers State.

On 3 August 1966 Ojukwu made a speech implying the 'inevitability' of the break-up of Nigeria. On 31 August 1966 he organized the first Consultative Assembly in Enugu, ostensibly to enable minorities in particular to express their views 'frankly on matters that vexed' them (de St Jorre 1972:71). Initially 'representatives' from Rivers (Province) were hand-picked, but after some protest, communities were allowed to select their own representatives. Chief Harold Dappa-Biriye was one of the prominent Rivers intellectuals and professionals present who were predominantly Ijaw (coastal Kalabari, Okrika and Bonny) and Ikwerre. He openly expressed his desire to see the creation of Rivers State. Ojukwu, like Willink a decade earlier, argued that provincial administration and provincial assemblies would suffice to meet minority concerns without necessitating the creation of states. Little indication was given of how the assemblies would be staffed and how funds would be allocated to them.

The issue of states resurfaced at the adjourned Ad Hoc Constitutional Conference in Lagos and then at a second Consultative Assembly meeting in Enugu on 4 October 1966. This time 'people with doubtful loyalties were excluded' (Okara 1970 [rpt 2001]). Ojukwu gave the impression that he was acquiescing in the idea of state creation as long as it was not built on 'hate, fear and spite', that is, was not anti-Igbo. Many Eastern minority intellectuals, particularly those who were known to favour the creation of a Rivers State, started to feel the pressure to conform to Ojukwu's agenda. The Ikwerre writer Elechi Amadi, a former naval captain turned teacher, maintains that from September 1966 onwards 'detention camps sprung up all over the region' (Amadi 1973:20). He also claims that Ojukwu 'over used' photographs of the massacres to manipulate public opinion in the East and buoy up secessionist feelings on the part of the Igbo and minorities who had also been forced to return from the North, creating a refugee crisis.

On 27 May 1967, Ojukwu organized another forum, the Eastern Consultative Assembly, to which he invited 'all the chiefs and opinion leaders of the Eastern minorities', and during which he received a message from 
Gowon, who indicated that he would create new states if Ojukwu carried out his threat to secede. According to Elechi Amadi, one of the delegates, many minority leaders expressed fears of a Biafran state in which they would remain dominated by Igbos, but Ojukwu claimed that 'Easterners' gave their support (Amadi 1973:17). Common to Amadi's, Saro Wiwa's and other 'minority' accounts (Saro-Wiwa 1989:42) is the conviction that Ojukwu did not make sufficient attempts to stave off war but used the attacks on Igbos in the North, harrowing though they were, to justify a secessionist course on which he was already embarked long before the massacres took place. Of the killing and maiming of Igbos in Northern towns and cities between July and September 1966, Amachi comments, 'the casualties were carefully photographed and documented’ (Amadi 1973:15).

In the wake of the 29 July 1966 coup, Dappa-Biriye organized a group of minority politicians, businessmen and intellectuals, who subsequently became known as the 'Leaders of Thought of the Rivers People'. They met regularly in Port Harcourt with a view to developing a proposal for state creation. S.N. Dikibo, a Kalabari Ijaw lawyer, chaired the group. Ken Saro Wiwa, then a part-time teacher and postgraduate student at the University of Ibadan, was responsible for drafting the memorandum for a future state within a twelve-state arrangement (Williams 2000). The memorandum was signed by representatives of the six divisions in Rivers Province (Degema, Ahoada, Port Harcourt, Ogoni, Brass and Opobo), published on 14 September 1966 and presented by a Niger Delta Delegation, which included DappaBiriye, E.J.A Oriji and W.O. Briggs to the Ad Hoc Constitutional Conference called by Gowon to discuss the future of the Federation (Okara 1970 [2001]:10). Dappa-Biriye presented his memorandum to the Northern political establishment who accepted it. ${ }^{6}$

When Gowon announced the creation of twelve states, Alfred Papapiriye Diete-Spiff, an Ijaw from Nembe/Brass (central Delta coastal saltwater) was appointed Military Governor of Rivers State. But the new Rivers state did not fulfil the dreams of Biriye's former Niger Delta Congres. It did not include Opobo division, which became part of South-Eastern State, nor the Western Ijaw, who stayed in the Mid-West Region/State. The creation of states, however, encouraged many Ijaw and other Niger Delta minority elites to rally together around the idea that they were all 'Rivers people' and that the state was created for them.

\section{Supporters of Circumstance and Saboteurs}

Many top Ijaw civil servants in the Eastern Region found themselves in a difficult position once the Republic of Biafra was declared in May 1966. Some resigned and were subsequently imprisoned with other minorities. Many 
of those who had been actively involved in promoting a Rivers State were particularly targeted. Chief E. J. A. Oriji, who had presented the memorandum on State Creation at the Ad Hoc Constitutional Committee in September 1966, was tortured in detention. Most minority civil servants bit their lips and continued working. Amadi contends that 'their presence in the rebel camp provided the secessionists with a powerful argument against the minority issue' (Amadi 1973:42). Ignatius Kogbara, a prominent member of the Ogoni elite, was a member of the Biafra Public Service Commission and later Biafran Ambassador to the UK (Okonta 2002:159-60). Obi Wali, an Ikwerre, was originally hostile to Ojukwu's Biafran project but later became part of Biafra's propaganda machine. Okoko Ndem, an Efik, broadcast humorous and popular programmes on Radio Biafra. He swapped sides after the capture of Radio Biafra in 1968. ${ }^{7}$ Most Ijaw supporters of the Biafran cause had been NCNC stalwarts. After the war they justified their actions by claiming that if they had not been there (on the Biafran side) they would not have protected the interests of 'their people' while allowing the storm to pass. After the war former NCNC regional House of Assembly member, Frank Opigo, was seen as a traitor feathering his nest, was almost lynched and had to go into hiding. ${ }^{8}$

Yet within Biafra, minorities that chose to support the effort continued to arouse suspicion. Chimamanda Ngozi Adichie's novel is replete with references to persistent suspicions of minority commitment to the Biafra cause, constantly hounded for being saboteurs but equally instrumental in sustaining the Biafran effort, as professionals or fighters on the frontline. Adichie, while sympathetic to the Biafran cause, critically explores how the saboteur syndrome was exploited politically, as a convenient way of dealing with all forms of political opposition to Ojukwu and shielding Biafrans from disillusionment with a failing and costly war enterprise. Ojukwu's persistent search for 'saboteurs' enabled him to explain away Biafran setbacks and defeats, suppress rivals and maintain control of power and weapons. Even Igbo Biafran soldiers were targeted (Madiebo 1980). The extent to which Wamo Weli-Wegbe's claim of a systematic plan by the Igbo to exterminate all minorities existed is difficult to ascertain, but finds resonance among some Ijaw nationalists (Oguoko:249). In 2001, Weli-Wegbe’s views, which were first expressed as conference proceedings in 1970, were published once again. This was at the same time as the Oputa Panel into Human Rights Abuses in Nigeria received submissions from Igbo delegations about atrocities committed against the Igbo during the civil war. Unsettled scores between minorities and their Igbo neighbours provide a backdrop to current tensions between the Igbo and Eastern minorities. These are being replayed in the 
context of oil community protests that pit 'indigenes' against 'strangers' and challenge oil companies to end 'majority' (read Igbo) domination of the oil and oil servicing industry from which minorities feel they have been excluded.

Rivers State has been numerically and politically dominated by the Ijaw since its creation in 1967 and following its division in 1996 into Rivers and Bayelsa States. Against this backdrop post-war Ijaw narratives have long suggested that the Ijaw did not support Biafra but rather the One Nigeria agenda of the Nigerian Federal government. During the war itself, Isaac Boro's legacy of opposition to the Igbo-dominated Eastern Regional Government was the prevailing ideology within the Biafran leadership. The Kolokuma-Opokuma clan area, in which the town of Kaiama is situated, was targeted because it was perceived by the Biafran regime as a bastion of antiBiafra sentiment. For this reason as well as because of 'Boro's legacy', many Kaiama boys escaped to join the Federal forces. In Anyama, in today's Southern Ijaw LGA, resistance to Biafra is etched on to popular memory with a play enacted yearly to dramatize how the Izon sank Biafran boats.

Village-level case-study research, however, reveals a different, less blackand -white picture of the Ijaw and war. 'Support' for Biafra in ideological terms even among those deemed to be part of the prototypical Biafra constituency, shifted as the war progressed. Even those ideologically committed to the war, in contexts of scarcity did what was necessary to survive - many avoided conscription, and traded over enemy lines. The socalled 'attack trade' ('Afia-attack) involved trading groups who for centuries had traded across the northern parts of the Delta and Igbo hinterland. How active ideological support or resistance to Biafra could have been was also circumstantial, affected by how close one was to the frontline or where one was when the war broke out. Many Ijaw teachers from the central Delta were caught in Owerri and Enugu when war struck. Owerri was captured and recaptured by both sides. Many found ways to avoid conscription into the Biafran army trekking over huge distances and swimming across rivers where necessary. Chief Abule, then a primary school teacher and today paramount ruler of Oporoma, in Southern Ijaw recounts how he escaped from Owerri by playing dumb. 'We pretended to be fools ... when they said "about turn", we would sit down ... when they asked "what is the time?", we would say "the long hand of the clock is on top of the small hand" ... they would then say "Come on, get out ... these are bush people". ... So we managed to escape conscription and the sudden killing of soldiers.. ${ }^{19}$ Abule later moved to Lagos and 'became an errand boy for the Rivers State Government' in exile.

Most young men from Yenagoa Province fled to Ekeremor and Sagbama, which were then part of Western Ijaw division in the Mid West Region, or to 
Lagos. On arrival, some squatted there with Ijaw refugees who had been forcibly repatriated from Ghana. Frustrated by their insecure status, many joined the Federal Army. Others moved to Ajegunle on the outskirts of Lagos an area with a long history of exchange with Ijaw communities further east in the Niger Delta and the site of many early Ijaw settlements along the creeks.

Yet many Ijaw living outside the frontline areas stayed put and at one time or other were 'roped in' to the Biafran effort. The Edoid-speaking Epie from Yenagoa (who are now considered by Ijaw nationalists to be part of a pan-Ijaw ethnic family even though their language is more like Edo/Benin languages than any of the Ijaw languages), situated at the gateway to the riverine Delta (Southern Ijaw) were of strategic importance during the war to the Biafran forces stationed in nearby Mbiama junction. Many Epie and Atissa (similarly Edoid-speaking) made money through the 'attack trade' using subterfuge to bypass blockades on Biafra imposed by the Nigerian Federal forces stationed in Yenagoa itself. Igbo women traders from towns and villages to the north of the Delta, using old networks, entrusted large amounts of money often hidden in dug-out canoes to Epie intermediaries. After the capitulation of Port Harcourt in September 1968, Biafran forces clamped down on the Epie and Atissa, who were suspected of being saboteurs. Able-bodied men were taken from villages to refugee camps in Ahoada and tortured. They were only released after the intervention of known Epie supporters of the Biafra cause, such as former NCNC stalwart, Chief Mabinton (Eboreime 1992:86).

Just as Ike Okonta's $(2002,2007)$ work has shown that Biafra was an opportunity for the Ogoni to recast themselves in a new and more powerful political light, many Epie and Atissa youth, like other 'micro-minorities', desperately sought to join the Biafran effort. For them, the Biafran army offered a vehicle for upward social mobility in a context in which they found themselves persistently outdone by their Ijaw-proper 'brothers' who tried to absorb them ideologically while keeping them at the margins politically and economically because they were 'not quite' Ijaw. Like many Ogoni, they were not keen on a Rivers State, which would have meant their continued domination and political marginalization by larger 'minority' groups like the Ijaw.

Individual support for Biafra among political elites was not determined by ethno-political loyalties, but by past trajectories. Long-standing political differences between villages exploded during the war and conditioned relations between whole villages that continue today. Most people in the Kolo/Emeyal area in Ogbia division of Yenagoa Province were opposed to Biafra ideologically; but the most influential figures in the villages, notably those in the military who had been called back to the Eastern Region after the July 
coup and the massacres that followed, joined up with the Biafran army as a vehicle for speedy promotion. In the village of Emeyal, elites had been very pro-NCNC and supported Biafra. The neighbouring village of Imiringi had been very pro-NDC and supported Isaac Boro's secessionist movement in February 1966. Imiringi was consequently particularly at risk from Biafran reprisals because it was seen as a den of support for Isaac Boro. Heavy fighting took place in Emeyal between the Nigerian and Biafran forces. Influential local elites who had been NCNC supporters were severely sanctioned by the Nigerian army. Their houses were damaged while those accused of 'betrayals' were often slaughtered. When people ran away from Emeyal, people from the neighbouring village of Kolo looted their houses. This created subsequent problems between the two villages, which were further exacerbated by the oil finds of the 1970s in the Kolo Creek area. ${ }^{10}$

\section{Concluding Remarks}

Where does this leave us? What I have tried to do is present a picture of the multiple Ijaw experiences of the Biafran War, on both sides of the frontline, with some examples of how particular individuals by force or volition switched sides at particular moments. Forty years on, amid their own struggles with the Nigerian state, many of the Ijaw who fought on the Federal side against Igbo domination now look to Biafra as a symbol of Ijaw nationalism.

Oil community protests against the Federal government began in the early 1990s with Ken Saro Wiwa's MOSSOP. Since then these struggles have given rise to a number of Ijaw nationalist groups, cuminating most recently in the formation of MEND - the Movement for the Emancipation of the Niger Delta - a hydra-headed, largely Ijaw-led, armed militant movement, with multiple open conflicting objectives and strategies. These ethnic nationalist movements have changed the social and political geography of the Niger Delta, turning Biafra from a threat into an icon of liberation

As early as 1993, Ken Saro Wiwa was already 'extending a hand of friendship' to Ohaneze Ndi Igbo, the pan-Igbo socio-cultural organization, requesting support for his movement. By 2002, Alhaji Asari Dokubo, then President of the Ijaw Youth Council, had already begun to build political links with the militant Igbo organization MASSOB. In September 2005, both Dokubo and MASSOB's leader, Ralph Uwazurike, were arrested and charged with treason. Dokubo was released in June 2007, and rearrested in December 2007. To understand the impetus behind these new political shifts and the reworking of historical memories that they are generating, one needs to look at these movements (IYC, MEND, MASSOB) not simply as 'ethnic movements' but as 'generational' challenges to the status quo - a critique of 
strategies pursued by elites from each ethnic group, and an attempt to reverse them. Interestingly, it is the radical political strands within ethnic nationalist movements that have tended to sign up to the Biafran agenda, represented by MASSOB. It is not without significance that appeals have also been made to other Niger Delta minority groups by MASSOB to join their struggle and build common cause around their opposition to a centrally controlled federalism that allows little room for minority autonomy. The prevalence of 'minority narratives' among the Igbo, who rail against their 'minority' status within the Wazobia triad has also created space, at least conceptually, for the 'coming together' of Igbo and minority causes.

In a context of increasing popularization of the Biafra story among disenfranchised Igbo youth, it is difficult to tell just how far strategic alliances between MASSOB and Ijaw/Niger Delta minority nationalism will go. The search for common ground needs to contend with persistent inter-ethnic tensions that pull both groups in different directions. Patterns of intermarriage, historical ties and even shared memories of support for Biafra may exist, but gripes between Igbo and Ijaw remain unresolved - 'abandoned' properties in Port Harcourt after the war, Igbo positions in the oil and oil-servicing industry', the politics of indigeneity, which creates differential citizenship rights for migrant settlers and native populations of states and local government areas in a context of high rates of internal migration, are just some of a list of sticking points.

The purpose of excavating these narratives is not to arrive at a single truth about the war, if at all one exists. Truth alone would not help to heal the wounds opened by war, nor does it explain the new meanings drawn from the war by other marginalized groups within Nigerian society. While the Biafran War did not reshape Nigeria, its impact on Nigerian political and societal imaginary is less well understood. The aim of this paper has been to open up a discursive space around silenced aspects of Nigeria's and Biafra's history, making it possible to explore the ways in which memories of Biafra have been reworked into new political messages. Given the highly fragmented Nigerian and Niger Delta landscape, with high levels of inter- and intra-ethnic antagonism, rethinking Biafra may pave the way for the rebuilding of bridges between erstwhile 'enemies', crystallizing new alliances and new struggles for a more just and inclusive state.

\section{Notes}

1. Interview with Samuel Owonaru, July 2002, Kaiama.

2. Interview with Patrick Naagbaaanton, Ogoni journalist, July 2002, Port Harcourt.

3. Hosiah Emmanuel, 'Who Killed Adaka Boro?', http://www.unitedijawstates. com/boro.htm. 
4. Interview with Marlin T. Marlin (Director of Intelligence under Dokubo-led IYC), 31 May 2002, Port Harcourt.

5. Interview with Harold Dappa Biriye, 2 July 2002, Port Harcourt.

6. Interview with Chief Harold Dappa Biriye, March 2002, Port Harcourt.

7. Interview with Patrick Naagbaanton, July 2002, Port Harcourt.

8. Interview with O. A. Egberipou, August 2002, Port Harcourt.

9. Interview with H. R. H. Chief Abule, Paramount Chief of Oporoma, 20 April 2002, Oporoma, Bayelsa State.

10. Interview with Chief Atata, 28 June 2002, Imiringi, Bayelsa State.

\section{References}

Adichie, C. N., 2007, Half of A Yellow Sun, London: HarperCollins.

Amadi, E., 1973, Sunset in Biafra: A Civil War Diary, London: Heinemann.

Amaize, E., 2005, 'Arrest of Alamieyeseigha, Dokubo: Security Alert in Niger Delta Creeks', Vanguard, 24 September.

de St Jorre, J., 1972, The Nigerian Civil War, London: Hodder \& Stoughton.

Eboreime, O. J., 1992, Group Identities and the Changing Patterns of Alliances among the Epie-Atissa People of Nigeria 1890-1991, Cambridge: Cambridge University Press.

Emmanuel, H. (n.d.) 'Who Killed Adaka Boro?', online at http://www. unitedijawstates.com/boro.htm.

Jones, G. I., 1963, The Trading States of the Oil Rivers: A Study of Political Development in Eastern Nigeria, London: Oxford University Press.

Luckham, R., 1971, The Nigerian Military: 1960-1967, Cambridge: Cambridge University Press.

Madiebo, A. A., 1980, The Nigerian Revolution and the Biafran War, Enugu: Fourth Dimension.

Nwajiaku, K., 2006, 'La mémoire et l’oubli: Isaac Boro et les tendances du nationalisme Ijaw contemporain', Politique Africaine 103 (October).

Obasanjo, O., 1980, My Command, London: Heinemann.

Oguoko, B., 1999, Ijo Story: The History of the Ijo People: documentation and Notes, Izon Historical Documentation, London.

Okara, R. P. G., 1970, [rpt 2001]) 'The Rivers People and the History of the Nigerian Crisis in Rivers State', in Mofia T. Okobo, ed., The Rivers State, One Nigeria, Port Harcourt: Seanas Press.

Okonta, I., 2002, ‘The Struggle of the Ogoni for Self-Determination', unpublished D.Phil. thesis, University of Oxford.

Okonta, I., 2007, When Citizens Revolt: Nigerian Elites, Big Oil and the Ogoni Struggle for Self Determination, Trenton, NJ: Africa World Press.

Saro-Wiwa, K., 1989, On a Darkling Plain: An Account of the Nigerian Civil War, Port Harcourt: Saros.

Tamuno, T. N., 1972, 'Patriotism and Statism in Rivers State, Nigeria', African Affairs 71(284), July. 
Tebekaemi, T., ed., 1982, The Twelve Day Revolution, Benin City: Ethiope Publishing Company, Benin City: Umeh Publishers.

Weli-Wegbe, W., 2001, ‘Atrocities and Genocide’ in M.T. Akobo (ed.), The Rivers State in One Nigeria, Seanas Press, Port Harcourt, [1970], pp. 23-36.

Williams, E., 2000, 'Interview with Chief Harold Dappa Biriye', The Comet, October. Williams, G., 1982, The Nigerian Civil War, Milton Keynes: Open University Press. 